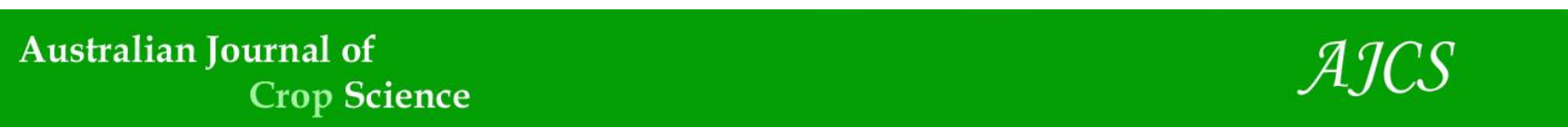

AJCS 15(04):594-601 (2021)

ISSN:1835-2707

doi: 10.21475/ajcs.21.15.04.p3054

\title{
Oil extraction and cake bromatological properties of crambe (Crambe abyssinica) are affected by extraction at different temperatures and rotation speeds
}

\author{
Cristiano Fernando Lewandoski ${ }^{*}$, Reginaldo Ferreira Santos, Doglas Bassegio, Samuel Nelson \\ Melegari de Souza, Jair Antonio Cruz Siqueira, Diane Maschio de Souza, Leonardo Silva Reis, \\ Paulo Lima Bueno
}

Universidade Estadual do Oeste do Paraná, UNIOESTE, CEP 85819130, Cascavel, PR, Brazil

*Corresponding author: cristiano.lewandoski@unioeste.br

\begin{abstract}
Temperature and rotation speed are operational parameters that influence oil screw press efficiency. The objective of this study was to evaluate the oil physicochemical properties, cake bromatological properties, and oil extraction yield from crambe (Crambe abyssinica Hochst) seeds by mechanical pressing at different temperatures and rotation speeds in a mechanical extruder. A $4 \times 5$ factorial experimental design was employed to determine the effects of these parameters. The experimental design incorporated four temperature ranges $\left(110-120,120-130,130-140\right.$, and $\left.140-150^{\circ} \mathrm{C}\right)$ and five screw rotation speeds $(1000,1200,1400,1600$, and 1800 rotations per minute, RPM), with four repetitions. The physicochemical properties of the oil and crambe cake, and the cake bromatological properties were affected by extraction at different temperatures and extruder rotation speeds. The oil density and viscosity (quality parameters), and the crambe cake bromatological factors, crude fiber, ash, lipid, and moisture content were found to be higher at extraction temperatures in the $140-150^{\circ} \mathrm{C}$ range. The maximum oil yield was achieved by extraction at a temperature of $140-150^{\circ} \mathrm{C}$ and a rotation speed of $1800 \mathrm{RPM}$. The protein and carbohydrate content of the crambe cake decreased with increasing temperature and rotation speed. The oil yield increased by $56 \%$ as temperatures increased from the $110-120^{\circ} \mathrm{C}$ range to the $140-150^{\circ} \mathrm{C}$ range, and by $41 \%$ when the rotation speed increased from 1000 to $1800 \mathrm{RPM}$. The screw configuration influenced the crambe and cake properties. These results can be used to determine the appropriate configuration of the screw.
\end{abstract}

Keywords: Crambe abyssinica Hoechst; Oil extraction; Screw press; Biodiesel.

Abbreviations: RPM_rotations per minute.

Introduction

Vegetable oils constitute a valuable class of biological resources, with applications in food and non-food industries; their production has been steadily increasing over the last twenty years (Uitterhaegen and Evon, 2017). Growing concerns regarding climate change and pollution have aroused interest in the use of non-food oils for the production of biofuel, owing to their cleaner burning and renewable nature (Leite et al., 2019; Costa, Almeida et al., 2019; Bhuiya et al., 2020). Crambe (Crambe abyssinica Hochst) seeds contain $35-45 \%$ oil, and up to $55-60 \%$ of this oil is composed of erucic acid, which is unsuitable for human consumption, but its demand is high in industries, including the manufacture of oils, lubricants, plastics, and biodiesel (Bassegio et al., 2016; Silveira et al., 2017; Costa et al., 2019).

Mechanical extraction is the most often used method for the removal of oil from oilseeds (Sriti et al., 2011; Sriti et al., 2012; Kartika et al., 2010; Bhuiya et al., 2020). This method is highly effective and can be performed in a single step in a continuous mode (Evon et al., 2014; Evon et al., 2015). Mechanical pressing provides a simple means of processing (Singh et al., 2002).
The main parameters that influence the performance of a continuous press are the rotation speed, pressure applied to the discharge area and presses with modular screws, and screw configuration (Savoire et al., 2013). The rotation speed during continuous pressing corresponds to the speed at which the piston compresses seeds in a hydraulic press (Savoire et al., 2013). Depending on the type of oilseed used, an increase in thread rotation speed can increase (Akinoso et al., 2009) or decrease (Evangelista, 2009) the oil yield. Kartika et al. (2006) observed an increase in the yield of sunflower oil with increasing barrel temperature and rotation speed.

Temperature influences press performance in various ways (Savoire et al., 2013). High processing temperatures may significantly increase the deformability and mobility of the cellular structure of the oilseed (Bouvier and Campanella, 2014), which can increase the extraction efficiency (Karaj and Müller, 2011). Increases in press efficiency and output with concomitant heating are usually accompanied by a decrease in oil quality (Savoire et al., 2013).

Interactive effects of temperature and rotation speed on the physicochemical properties of crambe oil have not been reported in other studies. Screw pressing has been studied 
for a large variety of oilseeds, including linseed, canola, crambe, and chia (Savoire et al., 2013). In addition to the operational parameters, the characteristics of the raw material also affect the screw press performance. Studies have demonstrated that factors contributing to increased pressure and temperature in the screw barrel have a major positive influence on the oil yield (Rombaut et al., 2015). However, even if the temperature increases the oil yield and press capacity, this is usually accompanied by a decrease in oil quality (Savoire et al., 2013). These factors can be modulated by optimizing the diameter of the restriction die located at the meal discharge, and by modulating the screw rotation speed (lower speeds and smaller restriction openings increase yield) (Savoire et al., 2013). Jing and Chi (2013) observed that extrusion temperature $\left(115^{\circ} \mathrm{C}\right)$ and rotation speed (180 RPM) had a positive impact on the dietary fiber content of soybean meal. At present, there is no information in the literature regarding the effects of temperature and rotation speed on the nutritional value and chemical composition of the crambe cake. Information regarding the chemical composition and nutritional value of the cardoon press cake for ruminant nutrition is scarce and outdated. Byproducts generated during biodiesel production deserve investigation because many production chains will only be economically viable when these residues add value to the production systems (Souza et al., 2009). In addition, without a destination, the high volume of coproducts and byproducts may pose a problem due to their accumulation in the environment (Mendonça et al., 2015).

Crambe cake with high lipid content can have a deleterious effect on dietary assimilation of some nutrients (NRC, 2007), but can be a beneficial environmental factor because it can help mitigate enteric methane (Abdalla et al., 2008). The crambe seed coats are rich in lignified fiber, which remains in the cake after oil extraction. This high lignified-fiber content can reduce its usefulness in lamb feed (Canova et al., 2012).

In the present study, we hypothesized that processing conditions would influence important properties of the extracted oil as well as the crambe cake. The objective of this study was to evaluate (i) the physicochemical properties of the oil, (ii) the bromatological properties of the cake, and (iii) the yield of oil extracted by mechanically pressing seeds at different temperatures and rotation speeds in a mechanical extruder.

\section{Results}

\section{Physicochemical properties of the crambe oil}

The specific mass of the crambe oil was affected by the press temperature during extraction $(P<0.05$; Table 1$)$. A linear increase was observed in the specific mass of crambe oil from ( 0.8260 to $\left.0.8433 \mathrm{~g} \mathrm{~cm}^{-3}\right)$ when the temperature range during extraction increased from $110-120^{\circ} \mathrm{C}$ to $140-$ $150^{\circ} \mathrm{C}$ (Figure 2). The specific mass of crambe oil was not affected by the rotation speed ( $P=0.1747$; Table 1$)$.

The viscosity of the crambe oil increased significantly $(\mathrm{P}<$ 0.05 ; Table 1) from 49.72 to $50.98 \mathrm{~mm}^{2} \mathrm{~s}^{-1}$ as the temperature increased from $110-120^{\circ} \mathrm{C}$ to $140-150^{\circ} \mathrm{C}$ during extraction (Figure $3 \mathrm{~A}$ ). Increasing the rotation speed from 1000 to 1800 RPM increased the viscosity if the oil from 49.52 to $50.63 \mathrm{~mm}^{2} \mathrm{~s}^{-1}$ (Figure 3B).

The temperature $\times$ RPM interaction significantly affected $(P$ $<0.01$; Table 1) the crambe oil yield (Figure 4), which increased with increasing temperature or RPM (Table 2; Figure 4A). At 1600 and 1800 RPM, the yield of oil was similar, regardless of the extraction temperature (Table 2). Extraction at 1600 and 1800 RPM resulted in higher oil yields compared with that at 1100 and 1200 RPM. At high temperatures $\left(140-150^{\circ} \mathrm{C}\right)$, oil extraction at RPMs of 1400 , 1600 , and 1800 resulted in yields of $17.37 \%, 18.5 \%$, and $19.5 \%$, respectively. These values are statistically equal, and higher than the yield for extractions at 1000 or 1200 RPM, which provided yields of $13.75 \%$ and $15.12 \%$, respectively (Table 2; Figure $4 \mathrm{~A}$ and $\mathrm{B}$ ).

\section{Bromatological properties of crambe cake}

The interaction of temperature $\times$ RPM significantly affected $(P<0.05$; Table 1$)$ the carbohydrate content of the crambe cake (Figure 5). Increasing temperatures and RPM decreased the carbohydrate content of the crambe cake (Table 2; Figure $5 \mathrm{~A})$. At high temperatures $\left(140-150^{\circ} \mathrm{C}\right)$, oil extraction at 1600 and 1800 RPM resulted in lower carbohydrate content $(41.02 \%$ and $40.85 \%$, respectively; Table 2 ; Figure $5 \mathrm{~A}$ and $\mathrm{B})$.

The crude fiber content of the crambe cake was also influenced by temperature and RPM $(P<0.05$; Table 1 ; Figure 6), significantly increasing from $3.30 \%$ to $4.41 \%$ with an increase in extraction temperature from $110-120^{\circ} \mathrm{C}$ to $140-150^{\circ} \mathrm{C}$ (Figure $6 \mathrm{~A}$ ). Increasing the rotation speed from 1000 to 1800 RPM also increased crude fiber from $3.79 \%$ to 4.07\% (Figure 6B).

Crambe cake protein content was affected by temperature and RPM ( $<$ 0.05; Table 1; Figure 6). Protein content significantly decreased from $26.55 \%$ to $24.55 \%$ with an increase in extraction temperature range from $110-120^{\circ} \mathrm{C}$ to $140-150^{\circ} \mathrm{C}$ (Figure $6 \mathrm{C}$ ). Increasing the rotation speed from 1000 to 1800 RPM decreased protein levels from $25.57 \%$ to $25.14 \%$ (Figure 6D).

The lipid content of the crambe cake was influenced by temperature and RPM ( $P<0.05$; Table 1; Figure 6). Lipid levels significantly increased from $18.15 \%$ to $18.71 \%$ with an increase in extraction temperature from $110-120^{\circ} \mathrm{C}$ to 140 $150^{\circ} \mathrm{C}$ (Figure $6 \mathrm{E}$ ). Increasing the rotation speed from 1000 to 1800 RPM increased the crude fiber levels from $18.32 \%$ to $18.47 \%$ (Figure $6 F$ ).

The crambe cake ash content was also affected by temperature and RPM $(\mathrm{P}<0.05$; Table 1; Figure 7$)$. The ash content of the crambe cake significantly increased from $6.41 \%$ to $7.49 \%$ with an increase in extraction temperature from $110-120^{\circ} \mathrm{C}$ to $140-150^{\circ} \mathrm{C}$ (Figure 7A). Increasing RPM from 1000 to 1800 increased the crambe cake ash content from $6.84 \%$ to $7.09 \%$ (Figure $7 \mathrm{~B}$ ).

The moisture content of the crambe cake was affected by temperature and RPM ( $<<0.05$; Table 1; Figure 7); it significantly increased from $4.41 \%$ to $6.16 \%$ with an increase in extraction temperature from $110-120^{\circ} \mathrm{C}$ to $140-150^{\circ} \mathrm{C}$ (Figure 7C). Increasing RPM from 1000 to 1800 increased the moisture content of the crambe cake from $5.11 \%$ to $5.58 \%$ (Figure 7D)

\section{Discussion}

Operating conditions (rotation speed and pressing temperature) exerted an important influence on both the yield and quality of the expressed oil. The specific mass of crambe oil was sensitive to variation due to treatment conditions, increasing with increasing temperature (Figure 3). Evon et al. (2013) also observed a small variation of 0.910 to $0.917 \mathrm{~g} \mathrm{~m}^{-3}$ in the specific mass of Jatropha curcas oil in response to temperature changes. Sriti et al. (2012) observed 
Table 1. Physico-chemical and bromatological properties of oil on different temperatures and RPM in the extraction of crambe oil.

\begin{tabular}{|c|c|c|c|c|c|c|c|c|c|}
\hline \multirow[t]{2}{*}{ Sources of variation } & \multirow{2}{*}{$\begin{array}{l}\text { Specific } \\
\text { mass } \\
\mathrm{g} \mathrm{cm}^{-3}\end{array}$} & \multirow{2}{*}{$\begin{array}{l}\text { Viscosity } \\
\mathrm{mm}^{2} \quad \mathrm{~s}^{-1} \\
40^{\circ} \mathrm{C}\end{array}$} & \multirow[t]{2}{*}{ Oil yield } & \multirow[t]{2}{*}{ Carbohydrates } & \multirow[t]{2}{*}{ Protein } & \multirow[t]{2}{*}{ Lipids } & \multirow{2}{*}{$\begin{array}{l}\text { Crude } \\
\text { fiber }\end{array}$} & \multirow[t]{2}{*}{ Ash } & \multirow{2}{*}{$\begin{array}{l}\text { Cake } \\
\text { moisture }\end{array}$} \\
\hline & & & & & & & & & \\
\hline \multicolumn{10}{|l|}{ Temperature $\left({ }^{\circ} \mathrm{C}\right)$} \\
\hline $110-120$ & $0.8260 \mathrm{c}$ & $49.72 \mathrm{~b}$ & $10.7 \mathrm{a}$ & 43.41 & $26.45 \mathrm{~d}$ & $18.15 \mathrm{~d}$ & $3.30 \mathrm{~d}$ & $6.41 \mathrm{~d}$ & $4.41 \mathrm{~d}$ \\
\hline $120-130$ & $0.8334 \mathrm{~b}$ & $50.02 b$ & $13.0 \mathrm{~b}$ & 43.04 & $25.56 \mathrm{c}$ & $18.29 \mathrm{c}$ & $3.84 \mathrm{c}$ & $6.70 \mathrm{c}$ & $5.22 \mathrm{c}$ \\
\hline $130-140$ & $0.8338 \mathrm{~b}$ & $50.04 \mathrm{~b}$ & $15.1 \mathrm{c}$ & 42.49 & $24.89 \mathrm{~b}$ & $18.46 \mathrm{~b}$ & $4.23 \mathrm{~b}$ & $7.22 \mathrm{~b}$ & $5.62 \mathrm{~b}$ \\
\hline \multicolumn{10}{|l|}{$\mathrm{RPM}\left(\mathrm{min}^{-1}\right)$} \\
\hline 1000 & 0.8320 & $49.52 \mathrm{c}$ & $11.4 \mathrm{~d}$ & 42.90 & $25.57 \mathrm{c}$ & $18.32 \mathrm{~b}$ & $3.79 \mathrm{c}$ & $6.84 \mathrm{c}$ & $5.11 \mathrm{~d}$ \\
\hline 1200 & 0.8341 & 50.07 b & $12.9 \mathrm{c}$ & 42.77 & $25.48 \mathrm{bc}$ & $18.37 \mathrm{ab}$ & $3.86 \mathrm{bc}$ & $6.90 \mathrm{bc}$ & $5.25 \mathrm{~cd}$ \\
\hline 1400 & 0.8343 & $50.30 \mathrm{ab}$ & $14.3 \mathrm{~b}$ & 42.64 & $25.40 \mathrm{ab}$ & $18.39 \mathrm{ab}$ & $4.00 \mathrm{ab}$ & $6.96 b$ & $5.36 \mathrm{bc}$ \\
\hline 1600 & 0.8347 & $50.43 a b$ & $15.2 \mathrm{a}$ & 42.34 & $25.24 \mathrm{a}$ & $18.44 \mathrm{a}$ & $4.02 \mathrm{ab}$ & $6.98 \mathrm{~b}$ & $5.46 a b$ \\
\hline 1800 & 0.8349 & $50.63 \mathrm{a}$ & $15.7 \mathrm{a}$ & 42.23 & $25.14 \mathrm{a}$ & $18.47 \mathrm{a}$ & $4.07 \mathrm{a}$ & $7.09 \mathrm{a}$ & $5.58 \mathrm{a}$ \\
\hline ANOVA & & & $-\mathrm{P}-\mathrm{V}$ & je & & & & & \\
\hline Temperature (A) & $<0.000$ & $<0.000$ & $<0.000$ & $<0.000$ & $<0.000$ & 0.0021 & $<0.000$ & $<0.000$ & $<0.000$ \\
\hline RPM (B) & 0.1747 & $<0.000$ & $<0.000$ & $<0.000$ & $<0.000$ & $<0.000$ & $<0.000$ & $<0.000$ & $<0.000$ \\
\hline$A \times B$ & 0.4908 & $<0.056$ & 0.010 & $<0.000$ & 0.4202 & 0.7305 & 0.9151 & 0.2036 & 0.4218 \\
\hline
\end{tabular}

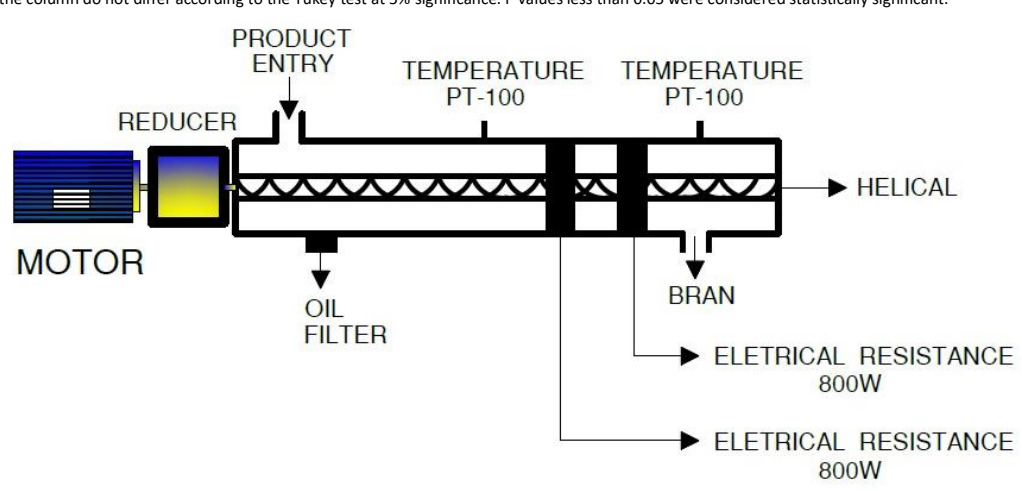

Fig 1. Schematic of extruder used in the experiment showing the main components.

Table 2. Unfolding the interaction temperature $\times$ RPM for oil yield and carbohydrates.

\begin{tabular}{|c|c|c|c|c|}
\hline \multirow{3}{*}{$\operatorname{RPM}\left(\mathrm{min}^{-1}\right)$} & \multicolumn{4}{|c|}{ Temperature $\left({ }^{\circ} \mathrm{C}\right)$} \\
\hline & $110-120$ & $120-130$ & $130-140$ & $140-150$ \\
\hline & \multicolumn{4}{|c|}{ Oil yield (\%) } \\
\hline 1000 & $8.37 \mathrm{dC}$ & $11.50 \mathrm{bB}$ & $12.12 \mathrm{cB}$ & $13.75 \mathrm{cA}$ \\
\hline 1200 & $9.87 \mathrm{cdC}$ & $12.50 \mathrm{bB}$ & $14.37 \mathrm{bA}$ & $15.12 \mathrm{cA}$ \\
\hline 1400 & $10.87 \mathrm{bcC}$ & $13.00 \mathrm{abB}$ & $16.12 \mathrm{aA}$ & $17.37 \mathrm{bA}$ \\
\hline 1600 & $12.00 \mathrm{abD}$ & $14.12 \mathrm{aC}$ & $16.37 \mathrm{aB}$ & $18.50 \mathrm{abA}$ \\
\hline \multirow[t]{2}{*}{1800} & $12.75 \mathrm{aC}$ & $14.25 \mathrm{aC}$ & $16.50 \mathrm{aB}$ & $19.50 \mathrm{aA}$ \\
\hline & \multicolumn{4}{|c|}{ Carbohydrate (\%) } \\
\hline 1000 & 43.75 aA & $43.17 \mathrm{aB}$ & $42.77 \mathrm{aC}$ & $41.92 \mathrm{aD}$ \\
\hline 1200 & $43.55 \mathrm{abA}$ & $43.25 \mathrm{aB}$ & $42.65 \mathrm{aC}$ & $41.72 \mathrm{aD}$ \\
\hline 1400 & $43.25 \mathrm{bcA}$ & $43.15 \mathrm{aB}$ & $42.57 \mathrm{aC}$ & 41.42 bD \\
\hline 1600 & $43.22 \mathrm{cdA}$ & $42.82 \mathrm{bB}$ & $42.30 \mathrm{bc}$ & $41.02 \mathrm{cD}$ \\
\hline 1800 & $43.12 \mathrm{dA}$ & $42.80 \mathrm{bB}$ & $42.17 \mathrm{bC}$ & $40.85 \mathrm{cD}$ \\
\hline
\end{tabular}

Values followed by a different lowercase letter are significant difference between RPM under same temperature. Values followed by a different capital letter are significant difference among temperatures under same RPM (Tukey test, $\mathrm{P}$ $<0.05$ ).

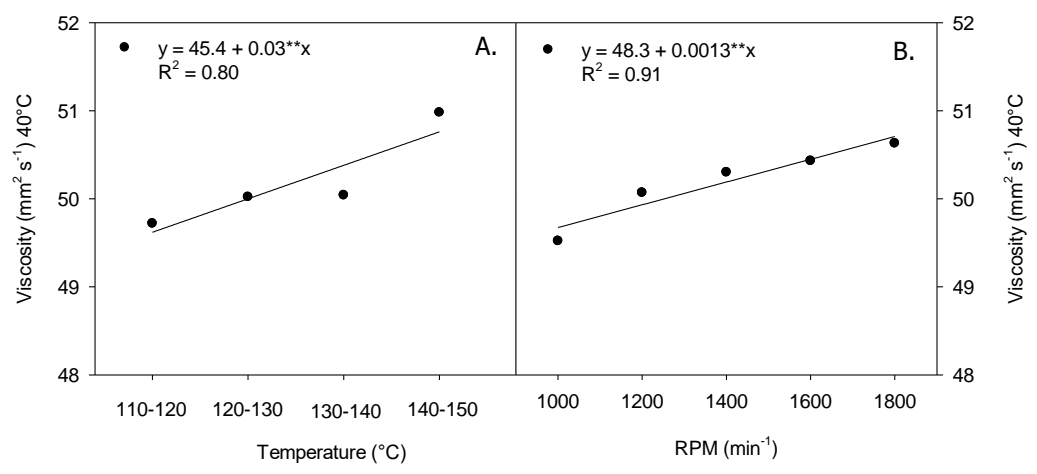

Fig 3. Viscosity at $40^{\circ} \mathrm{C}$ on different temperatures (A) and RPM (B) in the extraction of crambe oil. ** Significant at $P<0.01$ probability $(n=4)$. 


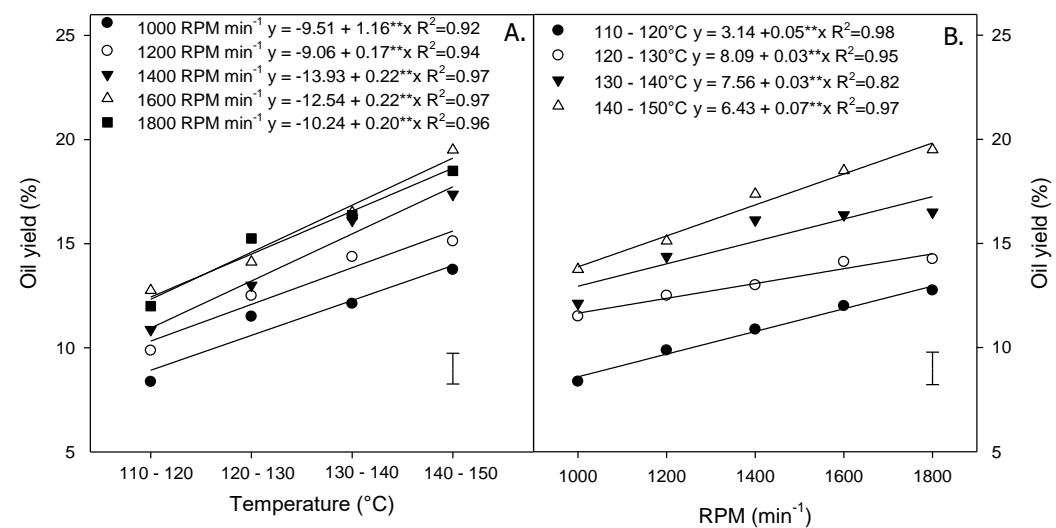

Fig 4. Interaction between temperatures (A) and RPM (B) for oil yield in the extraction of crambe oil. ** Significant at $p<0.01$ probability. Bars indicate least significant difference (LSD) by Tukey test at $P<0.05$ probability $(n=4)$.

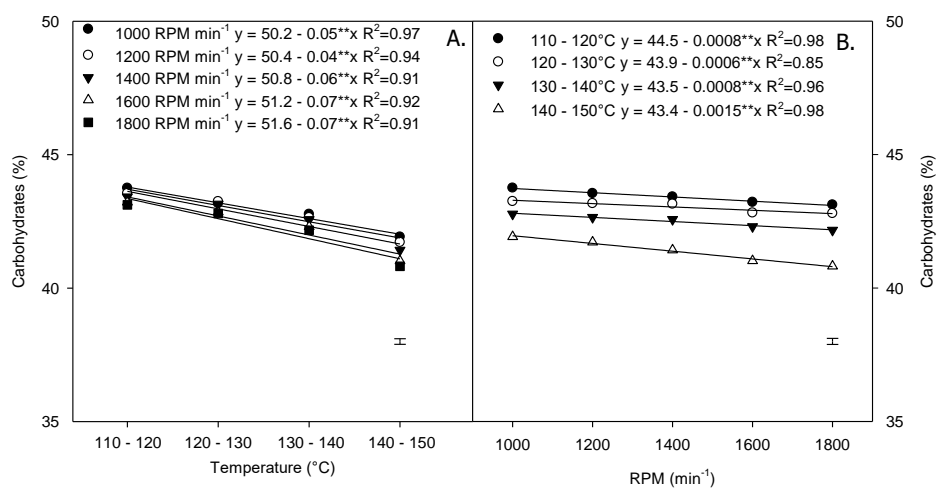

Fig 5. Interaction between temperatures (A) and RPM (B) for oil carbohydrates in the extraction of crambe oil. ${ }^{* *}$ Significant at $P<$ 0.01 probability. Bars indicate least significant difference (LSD) by Tukey test at $P<0.05$ probability $(n=4)$.

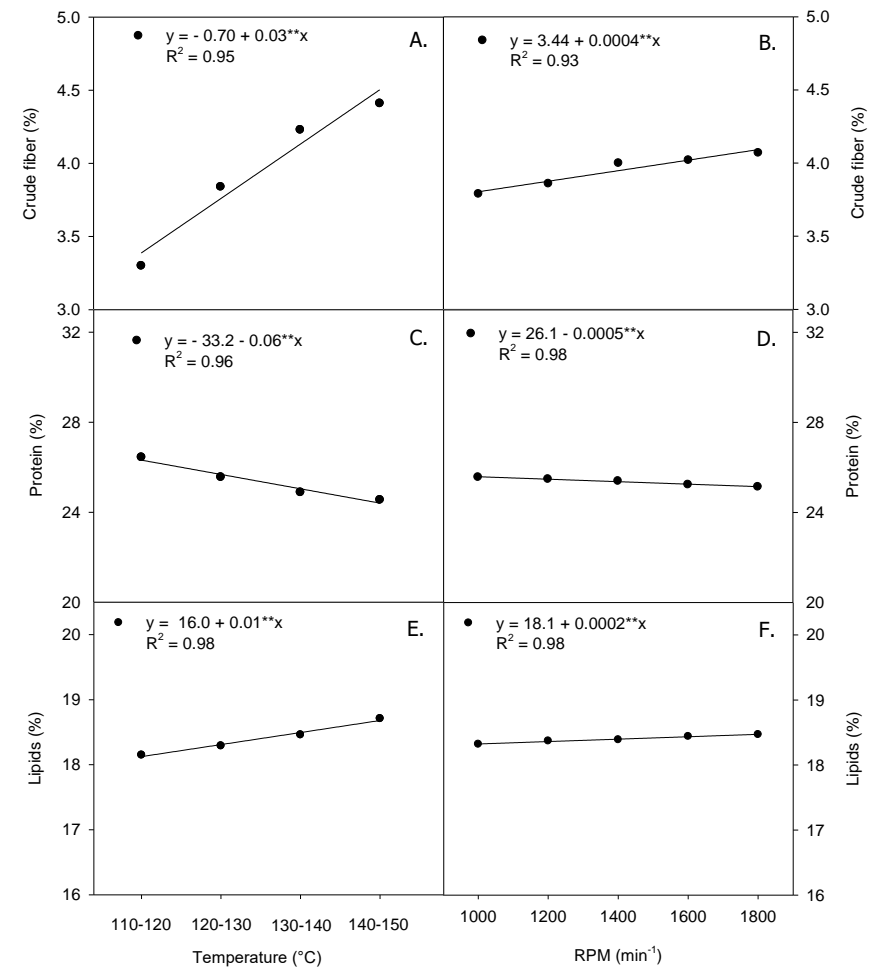

Fig 6. Crude fiber ( $A$ and $B)$, protein $(C$ and $D)$ and lipids $(E$ and $F$ ) on different temperatures and RPM in the extraction of crambe oil. ** Significant at $P<0.01$ probability $(\mathrm{n}=4)$. 


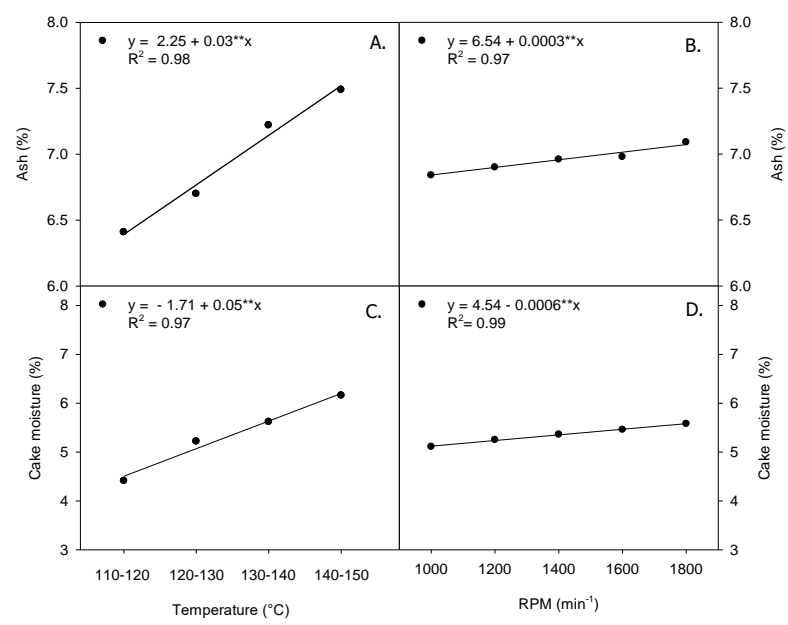

Fig 7. Ash ( $A$ and $B)$ and cake moisture $(C$ and $D)$ on different temperatures and RPM in the extraction of crambe oil. ${ }^{* *}$ Significant at $P<0.01$ probability $(\mathrm{n}=4)$.

observed no effects on Coriandrum sativum oil quality with different press configurations.

The viscosity of crambe oil increased as a function of increasing temperature (Figure 4A). Pressing temperature impacts several different aspects of the output of pressing through extrusion. Increasing temperature leads to a decrease in oil viscosity and coagulation of the seeds' protein fraction, thereby increasing the capacity of the press to express the oil, thereby facilitating its release through the fibrous matrix (Dufaure et al., 1999).

Our results show that increasing the temperature favors efficient extraction of crambe oil. The crambe oil yield increased by $56 \%$ as the temperature increased from 110 $120^{\circ} \mathrm{C}$ to $140-150^{\circ} \mathrm{C}$ (Figure $4 \mathrm{~A}$ ). While increasing temperature may facilitate extraction, it can distort lipoproteins, favoring the coalescence of fat globules and their subsequent exit from the plant cell (Wiesenborn et al., 2002).

High processing temperatures may approach the glass transition temperature of the cake material, causing a significant increase in the deformability and mobility of the cellular structure. This in turn leads to greater oil extraction (Bouvier and Campanella, 2014). The positive impact of high temperatures has been observed in the pressing of sunflower seeds, where an oil extraction efficiency of $66 \%$ was obtained at $80^{\circ} \mathrm{C}$, whereas $70 \%$ was obtained at $120^{\circ} \mathrm{C}$ (Dufaure et al., 1999). Although heating may increase the press performance and oil yield, this is usually accompanied by a decrease in oil quality (Savoire et al., 2013). Increasing the extraction temperature increased the viscosity of the crambe oil. Several problems are associated with the use of vegetable oils as fuel in compression ignition engines, mainly stemming from their high viscosity. The high viscosity of these oils is due to the large molecular mass and chemical structure of vegetable oils, which can hamper effective pumping, combustion, and atomization in diesel engine injection systems (Pramanik, 2003). The viscosity of biodiesel made from crambe oil can be reduced to acceptable levels by mixing it with another type of biodiesel or producing biodiesel from a mixture of less viscous oils (Costa et al., 2018).

In the mechanical pressing of $J$. curcas oil through a doublescrew extruder, Evon et al. (2013) observed yields of 56\%, $41 \%$, and $46 \%$ at temperatures of 80,100 , and $120^{\circ} \mathrm{C}$, respectively, indicating generally reduced yields above a threshold of $80^{\circ} \mathrm{C}$. Kartika et al. (2005) observed increases in the yield of sunflower oil as the barrel temperature and speed of rotation increased. At a screw rotation speed of 150 RPM, increasing the pressing temperature from 80 to $120^{\circ} \mathrm{C}$ did not improve the efficiency of oil extraction from $\mathrm{J}$. curcas (Evon et al., 2013).

The oil yield increased by $38 \%$ when the RPM was increased from 1000 to 1800 RPM (Figure 4B). Generally, the speed of the bolt rotation affects the yield of oil. Increasing the speed of rotation of the screw increases the filling of the thread, and the pressing time in the pressing zone is increased (Kartika et al., 2010).

\section{Bromatological properties of crambe cake}

There is little information in the literature regarding the nutritional value of mechanically extruded crambe cake, indicating that this type of cake has not been intensively studied in animal nutrition research. The bromatological properties of crambe cake were influenced by extraction at different temperatures and rotation speeds (Figure 5, 6, and 7). The extrusion process is economically viable, and it is of fundamental importance that byproducts of extraction, such as the cake, have industrial applications (Uitterhaegen et al., 2015). Crambe cake in small quantities can be used in animal feed to partially replace protein from soybean meal. The use of crambe cake in animal feed is an important strategy for the allocation of crambe remains, with the potential to add value to farming and promote sustainability of the production chain (Bassegio et al., 2016). Seneviratne et al. (2011) observed how screw speed and heat interacted to affect the properties pressed canola cake. Temperature is one factor that modulates the effectiveness of the extrusion process. The dietary fiber content of soybeans increases with increasing extrusion temperature up to $110^{\circ} \mathrm{C}$ (Jing and Chi, 2013). Increasing temperature can also increase food degradation, thereby increasing crude fiber content (Menezes et al., 2012).

The crambe cake lipid content increased slightly with temperature and RPM (Figure 7E and F). High temperatures induce greater oil fluidity, break the walls of additional fat cells, and promote coagulation of the protein fraction. Lipid droplets are easily released through the fibrous matrix toward the surface of the material, which increases the 
content of residual oil in the cake flour due to a reduction in seed plasticity (Wiesenborn et al., 2001; Kartika et al., 2005). The lipid content values ranged from $18.15 \%$ to $18.47 \%$, close to the $18.40 \%$ determined by Carrera et al. (2012) for crambe cake.

Protein content ranged from $24.55 \%$ to $25.56 \%$ (Figure $7 C$ and D), similar to the value of $24.2 \%$ observed by Mendonça et al. (2015) for crambe cake. These values are relatively high, allowing these cakes to be classified as potential protein foods in animal diets (Abdalla et al., 2008). However, before incorporating these coproducts into a food source, studies on toxicity and anti-nutritional factors are necessary to ensure their safety (Souza et al., 2009). The protein content of the crambe cake decreased with increasing temperature and rotation speed. In addition, the protein yield decreased when the extraction temperature was higher than $77^{\circ} \mathrm{C}$. According to Selling et al. (2013), it is reasonable for protein content to change with temperature, as proteins are sensitive to heat denaturation. Temperature may also affect the secondary and tertiary structure of proteins (Selling et al., 2007). Toghyani et al. (2015) observed that at high conditioning temperatures, the additional heat generated during the expulsion process at high screw torque resulted in lower digestibility. This was likely due to protein denaturation. At low or medium conditioning temperatures, the mechanical shear force under high screw torque improved the digestibility. This was likely caused by the release of encapsulated protein bodies from cell wall matrices.

\section{Materials and methods}

\section{Characterization of the experimental area and raw material}

The present study was conducted in the laboratory of the Center for the Development of Technological Diffusion of the Renewable Energy Laboratory of Unioeste (CDTER), in partnership with the Foundation for Scientific and Technological Development (FUNDETEC), Cascavel - PR, Brazil. Crambe seeds (cv. Brilhante) were supplied by the Agronomy Institute of Paraná, Brazil (IAPAR).

\section{Automated mechanical extruders}

Studies were performed with a mechanical extruder (Z-1500 Galvão Insumos Inputs, Iracema do Oeste, Brazil), wired to accept $220 \mathrm{~V}$ ac, with a $0.5 \mathrm{CV}$ engine for feed grains, and a 7.5 CV SEW main engine (Figure 1). Extrusion procedures were performed using the latest automation technology 4.0, with a PLC S7-1200 CPU1215C, an Hmi Touch KTP900, and two inverters (model G120C), all manufactured by Siemens. All equipment was operated using the Profinet network "Internet" This protocol allows rapid communication of commands between extruder hardware and other external hardware as needed. To measure the temperature, type PT100 sensors, model FSB-RTD-BRA-T60-U23-B03-C15-BF Novus, with a scale of $-100^{\circ} \mathrm{C}$ to $+400^{\circ} \mathrm{C}$, were used to convert the electrical signal from EN100 to 4-20 m. A TxBlock (Novus) signal transducer was used.

Variation in spindle motor rotation speed (in RPM) during oil extraction was made possible by installing a Siemens model G120C frequency inverter. To control and adjust the rotation speed and temperature during an experiment, we installed a human machine interface in the equipment.

\section{Rotation and temperature}

A $4 \times 5$ factorial experimental design was employed to determine the effects of temperature and rotation speed in the crambe extruder. The experimental design incorporated four temperature ranges $(110-120,120-130,130-140$, and $\left.140-150^{\circ} \mathrm{C}\right)$ and five rotation speeds $(1000,1200,1400$, 1600 , and 1800 RPM), with four repetitions.

\section{Physical and chemical analysis methods}

\section{Oil yield}

After pressing, the oil was left to settle for five days, then the residue was decanted, and the oil was filtered on paper. Yield was determined by calculating the ratio between the mass of seeds that entered the process and the mass of oil obtained after filtration (Instituto Adolfo Lutz, 2008).

\section{Specific mass}

One kilogram of crambe seeds was weighed into a $1000 \pm 10$ $\mathrm{mL}$ beaker and vibrated in a Bertel Shaker for $5 \mathrm{~s}$. After this operation, the volume and density $\left(\mathrm{kg} \mathrm{m}^{-3}\right)$ were determined (Instituto Adolfo Lutz, 2008).

\section{Viscosity}

A Brookfield viscometer (LVDV-III+ model) was coupled to a thermostatic bath, allowing measurement of oil viscosity in the range of $40^{\circ} \mathrm{C}$, with a temperature measuring accuracy of $0.5^{\circ} \mathrm{C}$ (Instituto Adolfo Lutz, 2008).

\section{Bromatological analysis}

\section{Crude fiber}

Extraction was performed in a Soxhlet device with $2 \mathrm{~g}$ of sample. Petroleum ether was used as the solvent. The extract was filtered and heated in an oven, followed by weighing and repetitive heating and cooling until the weight became constant (Instituto Adolfo Lutz, 2008).

\section{Lipids}

Samples (2-5 g) were weighed on a filter paper and set using pre-degreased wire wool. The temperature was held constant throughout an 8 (4-5 drops per s) or $16 \mathrm{~h} \mathrm{(2-3}$ drops per s) extraction period. Extracts were then placed in a desiccator at ambient temperature (Instituto Adolfo Lutz, 2008).

\section{Protein}

Organic matter was decomposed, and the nitrogen content was transformed into ammonia. As the nitrogen content of protein is approximately $16 \%$, an empirical factor of 6.25 was used to transform $g$ of nitrogen in an extract into $g$ of protein (Instituto Adolfo Lutz, 2008).

\section{Carbohydrates}

A $5 \mathrm{~g}$ sample was repeatedly weighed in a porcelain container, then the degreased material was mixed with 100 $\mathrm{mL}$ of $70 \%$ alcohol and transferred to a $500 \mathrm{~mL}$ Erlenmeyer flask. This mixture was agitated for $1 \mathrm{~h}$, centrifuged, and the residue was cooled using water. Sodium hydroxide and hydrochloric acid were heated in an autoclave. Reduced sugars in the resulting solutions were quantitated by titration using method 038/IV (Instituto Adolfo Lutz, 2008). 


\section{Ash}

We performed a procedure circulated by the Adolfo Lutz Institute (2008), which involved weighing 5-10 g of sample in a pre-heated capsule, then drying in an oven until the ashes were white or slightly gray (Instituto Adolfo Lutz, 2008).

\section{Cake moisture}

The weighing plate and cover were first weighed using an analytical balance. Approximately $5 \mathrm{~g}$ of crambe seed sample was placed on the weighing plate. The plate was closed and weighed on a precision scale to within $1 \mathrm{mg}$. The plate and cover (with the cover removed) were then placed in an oven with an airflow and intake of air (model MA 035-MARCONI) previously maintained at $105 \pm 2^{\circ} \mathrm{C}$ for $3 \mathrm{~h}$ (Instituto Adolfo Lutz, 2008).

\section{Statistical analyses}

Data were evaluated using ANOVA in a $4 \times 5$ factorial scheme. Temperatures and rotation speeds were adjusted by regression to $5 \%(P<0.05)$ probabilities, and means were compared using the Tukey test. Differences were considered statistically significant at $5 \%(P<0.05)$, using the statistical software Sisvar ${ }^{\circledR}$ (Statistical Analysis Software, UFLa, Lavras, MG, Brasil).

\section{Conclusion}

The screw configuration and operating conditions exerted prominent effects on the yield and quality of oil extracted during the extrusion of crambe. The quality parameters of oil density and viscosity, and the bromatological properties of crude fiber, lipid, ash, and moisture content of crambe cake increased with increasing temperature. The oil yield also increased with increasing temperature and rotation speed. Protein and carbohydrate levels in the crambe cake decreased with increasing temperature and rotation speed. These results can be used to improve mechanical pressing of crambe seeds and indicate the most appropriate screw configuration.

\section{Acknowledgments}

We thank CNPq (National Council for Scientific and Technological Development), CAPES-Brasil (Coordination for Improvement.

Higher Education Personnel), UNASP - (Adventist University Center Engineer Coelho), Galvão Insumos (Project partner company) and PTI (Itaipu Technological Park) for the financial support to the authors. We also thank the Foundation for Scientific and Technological Development of the Municipality of Cascavel (FUNDETEC), Paraná, Brazil.

\section{References}

Akinoso R, Raji AO, Igbeka JC (2009) Effects of compressive stress, feeding rate and speed of rotation on palm kernel oil yield. J Food Eng. 93:427-430.

Bassegio D, Zanotto MD, Santos RF, Werncke I, Dias PP, Olivo M (2016) Oilseed crop crambe as a source of renewable energy in Brazil. Renew Sust Energ Rev. 66:311321.

Bhuiya MMK, Rasul M, Khan M, Ashwath N, Rahman M (2020) Comparison of oil extraction between screw press and solvent ( $\mathrm{n}$-hexane) extraction technique from beauty leaf (Calophyllum inophyllum L.) feedstock. Ind Crops Prod. 144:112024.

Canova ÉB, Bueno MS, Moreira HL, Possenti R, Brás P (2015) Crambe cake (Crambe abyssinica Hochst) on lamb diets. Ciênc Agrotec. 39:75-81.

Carrera RAB, Veloso CM, Knupp LS, Souza Júnior AHD, Detmann E, Lana RDP (2012) Protein co-products and byproducts of the biodiesel industry for ruminants feeding. Rev Bras Zootec. 41:1202-1211.

Costa E, Almeida MF, Alvim-Ferraz C, Dias JM (2019) The cycle of biodiesel production from Crambe abyssinica in Portugal. Ind Crops Prod. 129:51-58.

Costa E, Almeida MF, Alvim-Ferraz MC, Dias JM (2018) Effect of Crambe abyssinica oil degumming in phosphorus concentration of refined oil and derived biodiesel. Renew Energy. 124:27-33.

Dufaure C, Leyris J, Rigal L, Mouloungui Z (1999) A twinscrew extruder for oil extraction: I. Direct expression of oleic sunflower seeds. J Am Oil Chem' Soc. 76:1073-1079.

Evangelista RL (2009) Oil extraction from Lesquerella seeds by dry extrusion and expelling. Ind Crops Prod. 29:189196.

Evon PH, Kartika IA, Cerny M, Rigal L (2013) Extraction of oil from jatropha seeds using a twin-screw extruder: Feasibility study. Ind Crops Prod. 47:33-42.

Evon P, Vandenbossche V, Pontalier PY, Rigal L (2014) New thermal insulation fiberboards from cake generated during biorefinery of sunflower whole plant in a twin-screw extruder. Ind Crops Prod. 52:354-362.

Evon P, Vinet J, Labonne L, Rigal L (2015) Influence of thermo-pressing conditions on the mechanical properties of biodegradable fiberboards made from a deoiled sunflower cake. Ind Crops Prod. 65:117-126.

Instituto Adolfo Lutz (IAL) (2008) Normas analíticas do Instituto Adolfo Lutz: métodos físico-químicos para análise de alimentos. São Paulo: Instituto Adolfo Lutz.

Jing Y, Chi YJ (2013) Effects of twin-screw extrusion on soluble dietary fibre and physicochemical properties of soybean residue. Food Chem. 138:884-889.

Karaj S, Müller J (2011) Optimizing mechanical oil extraction of Jatropha curcas L. seeds with respect to press capacity, oil recovery and energy efficiency. Ind Crops Prod. 34: 1010-1016.

Kartika IA, Pontalier PY, Rigal L (2005) Oil extraction of oleic sunflower seeds by twin screw extruder: influence of screw configuration and operating conditions. Ind Crops Prod. 22:207-222.

Kartika IA, Pontalier PY, Rigal L (2006) Extraction of sunflower oil by twin screw extruder: Screw configuration and operating condition effects. Bioresour Technol. 97:2302-2310.

Kartika IA, Pontalier PY, Rigal L (2010) Twin-screw extruder for oil processing of sunflower seeds: Thermo-mechanical pressing and solvent extraction in a single step. Ind Crops Prod. 32:297-304.

Leite D, Santos RF, Bassegio D, Souza SNM, Secco D, Gurgacz $F$, Silva TRB (2019) Emissions and performance of a diesel engine affected by soybean, linseed, and crambe biodiesel. Ind Crops Prod. 130:267-272.

Mendonça BPC, Lana RP, Detmann E, Goes RHTB, Castro TR (2015) Crambe meal in finishing of beef cattle in feedlot. Arq Bras Med Vet Zootec. 67:583-90.

Menezes NLD, Pasqualli LL, Barbieri APP, Vidal MD, Conceição GM (2012) Temperaturas de secagem na integridade física, qualidade fisiológica e composição 
química de sementes de arroz. Pesqui Agropecu Trop. 42:430-436

Pramanik K (2003) Properties and use of Jatropha curcas oil and diesel fuel blends in compression ignition engine. Renew Energy 28:239-248.

Rombaut N, Savoire R, Thomasset B, Castello J, Van Hecke E, Lanoisellé JL (2015) Optimization of oil yield and oil total phenolic content during grape seed cold screw pressing. Ind Crops Prod. 63:26-33.

Savoire R, Lanoisellé JL, Vorobiev E (2013) Mechanical continuous oil expression from oilseeds: a review. Food Bioprocess Tech. 6:1-16

Selling GW, Hamaker SAH, Sessa DJ (2007) Effect of solvent and temperature on secondary and tertiary structure of zein by circular dichroism. Cereal Chem. 84:265-270.

Selling GW, Hojilla-Evangelista MP, Evangelista RL, Isbell T, Price N, Doll KM (2013) Extraction of proteins from pennycress seeds and press cake. Ind Crops Prod. 41:113119.

Silveira EV, Vilela LS, Castro CFS, Lião LM, Gambarra Neto FF, Oliveira P SM (2017) Chromatographic of the crambe (Crambe abyssinica Hochst) oil and modeling of some parameters for its conversion in biodiesel. Ind Crops Prod. 97:545-551.

Singh KK, Wiesenborn DP, Tostenson K, Kangas N (2002) Influence of moisture content and cooking on screw pressing of crambe seed. J Am Oil Chem' Soc. 79:165-170.

Souza ADVD, Fávaro SP, Ítavo LCV, Roscoe R (2009) Caracterização química de sementes e tortas de pinhãomanso, nabo-forrageiro e crambe. Pesq Agropec Bras. 44:1328-1335.
Sriti J, Talou T, Faye M, Vilarem G, Marzouk B (2011) Oil extraction from coriander fruits by extrusion and comparison with solvent extraction processes. Ind Crops Prod. 33:659-664.

Sriti J, Msaada K, Talou T, Faye M, Kartika IA, Marzouk B (2012) Extraction of coriander oil by twin-screw extruder: Screw configuration and operating conditions effect. Ind Crops Prod. 40:355-360.

Seneviratne RW, Beltranena E, Newkirk RW, Goonewardene LA, Zijlstra RT (2011) Processing conditions affect nutrient digestibility of cold-pressed canola cake for grower pigs. J Anim Sci. 89:2452-2461.

Uitterhaegen E, Nguyen QH, Sampaio KA, Stevens CV, Merah O, Talou T, Evon P (2015) Extraction of Coriander Oil Using Twin-Screw Extrusion: Feasibility Study and Potential Press Cake Applications. J Am Oil Chem' Soc. 92:1219-1233.

Uitterhaegen E, Evon P (2017) Twin-screw extrusion technology for vegetable oil extraction: A review. J Food Eng. 212:190-200.

Wiesenborn D, Doddapaneni R, Tostenson K, Kangas N (2001) Cooking indices to predict screw-press performance for crambe seed. J Am Oil Chem' Soc. 78:467-471.

Wiesenborn D, Doddapaneni R, Tostenson K, Kangas N (2002) Kinetic characterization of cooking-induced changes in crambe seed prepared for expelling. J Food Eng. 55:157163.

Toghyani M, Rodgers N, lji PA, Swick RA (2015) Standardized ileal amino acid digestibility of expeller-extracted canola meal subjected to different processing conditions for starter and grower broiler chickens. Poultry Sci. 94:9921002. 